\title{
TOB2 Gene
}

National Cancer Institute

\section{Source}

National Cancer Institute. TOB2 Gene. NCI Thesaurus. Code C104696.

This gene plays a role in cell cycle regulation. 